\title{
On-Street Parking and Traffic Flow Performance at Kapasan Shopping Area Surabaya
}

\author{
Amrita Winaya ${ }^{1 *}$ \\ ${ }^{I}$ ITATS, Jl.Arif Rahman Hakim 100 Surabaya Indonesia \\ *Corresponding author:dsw.amrita@gmail.com
}

(Received: January $9^{\text {th }}, 2020$; Revised: March $21^{\text {st }}, 2020$; Accepted: March $\left.23^{\text {rd }}, 2020\right)$

\begin{abstract}
Traffic congestion is a problem that is often faced by Indonesian big cities. It is related to land use in an area that causes on-street parking. The main cause is the imbalance between demand and supply, namely the need for parking during rush hour exceeds the capacity of existing parking. Another consequence is the increasing of side barriers resulting in the delays on certain roads. Shopping area in Jl.Kapasan, Surabaya is one of the densely areas attracted most people of Surabaya to conduct trading activities and shopping for daily needs. The denstiy of this region will affect the performance of traffic flow and causing delays. The study aims to identify on-street parking in Jl.Kapasan shopping area, consequences arising from parking on the road, and determine the level of service or performance of roads around this shopping area. The analytical methods used are derived from Indonesian Highway Capacity Manual 1997. Based on calculation and analysis, the capacity of Jl.Kapasan without parking on the road was 1468 $\mathrm{pcu} /$ hour and with on-street parking was only $1276 \mathrm{pcu} /$ hour.
\end{abstract}

Keywords: level of service; on-street parking; traffic performance

\section{Introduction}

Traffic problems especially in Indonesian big cities are very diverse. One of the problems is traffic congestion, which is a factor inhibiting the smooth flow of the traffic on the highway. In general, traffic congestion is related to land use factor in a region, such as a shopping district, educational area, office area, and so forth. Surabaya as the second largest city in Indonesia, has rapidly developed into a city with various functions of land use. Shopping areas, both traditional and modern has become one of the land use that causes congestion. The shopping area in Jl.Kapasan is a fairly dense area of trading activities and community attraction to shop for their daily needs. These activities resulted in an increase demand for parking vehicles, so that at certain times there is an imbalance between the needs of parking and parking capacity. The study was conducted to identify on-street parking in Jl.Kapasan, an area with a high traffic delay caused by parking vehicles on the road. The impact by the activity of on-street parking has also been analyzed, and the determination of level of service influenced by side barriers along Jl.Kapasan shopping district.

\subsection{Problems Formulation}

To promote the goals of the research, formulation of the problems need to be prepared that consist of:

1. How does the condition of on-street parking at Jl.Kapasan market area?

2. What is the parking volume and accumulation of on-street parking in the area? 
3. What is the road level of service at Kapasan shopping district due to the use of on-street parking?

\subsection{Study Objectives}

Based on the background of the problems, the purpose of this study can be formulated as follows:

1. To identify on-street parking at certain times around Jl.Kapasan market area;

2. To determine the parking volume and accumulation of on-street parking at Jl.Kapasan;

3. To analyze road level of service (LoS) at Jl.Kapasan shopping district, due to the effect of parking on the road and side friction.

\subsection{Scope of Problems}

In this research, there should be restrictions on the study to focus on the problems faced. The problem restrictions are as follows:

1. The study area is located at Jl.Kapasan, i.e. in the vicinity of the market that are used for parking on the road.

2. The study was only conducted on four-wheeled vehicle parking located on the road around Jl.Kapasan shopping area.

3. The volume of vehicles across Jl.Kapasan is calculated in accordance with the level of congestion at certain times intervals.

\subsection{Benefits}

In general, the research conducted is expected to give consideration to the relevant parties in formulating policies. Thus the congestion that occurs in Jl.Kapasan due to on-street parking can be significantly reduced.

\section{Utilization of Parking on the Roads}

Parking on the road that is not well managed can endanger safety and lead to high congestion and delays in the flow of traffic, especially public transport vehicles. Even in places where on-street parking spaces are well-organised, on-street parking can cause congestion if it is allowed to become full or close to full [1]. Many urban planners argue that residents who own cars will park on the streets if a building doesn't have enough off-street spaces [2].

\subsection{Parking Accumulation}

Parking accumulation is the number of vehicles parked at a certain time on a certain area, which is given by [3]:

$$
\text { Accumulation }=\mathrm{Ei}-\mathrm{Ex}+\mathrm{X}
$$

Ei : Vehicles entering the parking location

Ex : Vehicles that exit the parking location

$\mathrm{X} \quad$ : Number of existing vehicles

\subsection{Parking Volume}

Parking volume consists of parking capacity and the angle of parking, wherein the volume of parking denotes the number of vehicles included in the parking loads, i.e. the number of vehicles per given time period. Parking volume is calculated using the following formula:

$$
\text { Parking volume }=\mathrm{E} i+\mathrm{X}
$$

Ei : Vehicles entering the parking location

$\mathrm{X} \quad$ : Number of existing vehicles 


\subsection{Parking Space Units}

According to [3], parking space units or abbreviates as PSU is a guide used to determine the need for parking spaces. This is a comprehensive guide of the effective size to put a vehicle (passenger cars, buses/trucks, or motorcycles) including free space and wide opening doors. Parking space units are used to measure the needs of parking space, while its determination is based on the following considerations:

1. The dimensions at a standard vehicle

2. Free space of vehicle parking

3. The width of the vehicle door opening.

For each type of vehicle, the needs of PSU vary depending on the dimensions of the vehicle, as shown in Table 1.

Table 1. Determination of Parking Space Units (PSU) [3]

\begin{tabular}{|c|c|c|}
\hline No. & Vehicle Type & $\begin{array}{c}\text { Parking Space } \\
\text { Units } \\
\text { (in square meter) }\end{array}$ \\
\hline 1. & a. Passenger cars class I & $2.30 \times 5.00$ \\
\hline & b. Passenger cars class II & $2.50 \times 5.00$ \\
\hline & c. Passenger cars class III & $3.00 \times 5.00$ \\
\hline 2. & Bus/Truck & $3.40 \times 12.50$ \\
\hline 3. & Motorcycle & $0.75 \times 2.00$ \\
\hline
\end{tabular}

\subsection{Road Levels of Service}

The level of service is used to determine the performance of traffic flow (Level of Service- LoS). A road under certain conditions have different levels of service depending on various factors. The indicators of road level of service and traffic conditions are shown in Table 2 [4].

Table 2. Levels of Service [5]

\begin{tabular}{cccl}
\hline $\begin{array}{c}\text { Levels } \\
\text { of } \\
\text { Service }\end{array}$ & $\mathrm{D}=\mathrm{V} / \mathrm{C}$ & $\begin{array}{c}\text { Ideal } \\
\text { Velocity } \\
\mathrm{km} / \text { hour }\end{array}$ & \multicolumn{1}{c}{ Traffic Flow Characteristics } \\
\hline $\mathrm{A}$ & $<0.04$ & $>60$ & $\begin{array}{l}\text { Free flows operation, vehicles are almost } \\
\text { completely unimpeded in their ability to maneuver } \\
\text { within the traffic stream }\end{array}$ \\
\hline $\mathrm{B}$ & $0.04-0.24$ & $50-60$ & $\begin{array}{l}\text { Reasonably free flow, vehicles maneuver within the } \\
\text { traffic stream is only slightly restricted }\end{array}$ \\
\hline $\mathrm{C}$ & $0.25-0.54$ & $40-50$ & $\begin{array}{l}\text { Freedom to maneuver within the traffic stream is } \\
\text { noticeably restricted }\end{array}$ \\
\hline $\mathrm{D}$ & $0.55-0.80$ & $35-40$ & $\begin{array}{l}\text { Freedom to maneuver within the traffic stream is } \\
\text { more noticeably limited, and the driver experiences } \\
\text { reduced physical and psychological comfort level }\end{array}$ \\
\hline $\mathrm{E}$ & $0.81-1.00$ & $30-35$ & $\begin{array}{l}\text { Vehicles are closely spaced, leaving little room to } \\
\text { maneuver within the traffic stream at speed that still } \\
\text { exceed 49 mph }\end{array}$ \\
\hline $\mathrm{F}$ & $>1.00$ & $<30$ & Breakdowns in vehicular flow \\
\hline
\end{tabular}




\subsection{Road Capacity}

In relation to the capacity of a road, the factors that influenced it should be identified, as defined in [5] as follows:

$$
\mathrm{C}=\mathrm{Co} \times \mathrm{FCw} \times \text { FCsp } \times \text { FCsf } \times \text { FCcs }
$$

C : capacity (smp/hours)

Co : base capacity to certain conditions (idle) in pcu/hours

$\mathrm{FCw}$ : capacity adjustment factor for carriageway width

FCsp : capacity adjustment factor for directional split

FCsf : capacity adjustment factor for side friction

FCcs : capacity adjustment factor for city size

The term pcu means a metric used in transportation engineering, to assess traffic-flow rate on a highway [6]. Table 3 presents the value of passenger car equivalents (PCE) in accordance with the characteristics of the existing road:

Table 3. PCE for One-Way Divided Urban Roads

\begin{tabular}{lccc}
\hline \multirow{2}{*}{$\begin{array}{c}\text { Type of Road } \\
\text { One-way and divided }\end{array}$} & $\begin{array}{c}\text { Traffic Flow per Lane } \\
\text { (vehicle/hour) }\end{array}$ & \multicolumn{2}{c}{ pce } \\
\cline { 3 - 4 } Two-lane one-way (2/1) and & 0 & Heavy Vehicle & Motorcycle \\
Four-lane divided (4/2 D) & $\geq 1050$ & 1.3 & 0.40 \\
\hline Three-lane one-way(3/1) and & 0 & 1.2 & 0.25 \\
Six-lane divided (6/2 D) & $\geq 1100$ & 1.3 & 0.40 \\
\hline
\end{tabular}

Under the terms of IHCM, the wider the traffic lane, the FCw also becomes higher. The greatest value of traffic flow percentage in the opposite direction is achieved when the amount of traffic flow in that direction are $50 \%$ and $50 \%$. For side friction factor, its value becomes higher if the road is crowded and tend to be stalled due to the side barriers on the side of the road. As for the city size factor, the more the number of the population, the greater the factor value.

\section{Methodology}

The needs of parking space was determined using the Parking Space Unit (PSU), while the PSU itself depends on the dimensions of the vehicles.

\subsection{Preliminary Survey}

Prior to this research, some preparations are needed to expedite the acquisition of the data used for the analysis. Those preparations consist of observing the study site and literature reviews. The need for field observations related to the timing and location of the survey, i.e. the time interval during peak hour survey and off-peak, as well as the location of the survey to calculate the traffic volumes. Thus an accurate data is expected to be obtained. While the literature review is necessary to obtain an overview of previous studies that have been done, as well as literature related to the research topic.

\subsection{Data Survey}

To carry out this study, some data are needed to be used in analysis. These data consist of:

a) Primary data

In this study the primary data required is the amount of vehicles entering and exit the parking area (the type of vehicle and parking time should be noted), as well as traffic volume data and the number of vehicles parked on the road in the segment of Jl.Kapasan in front of the shopping district. Acquisition of primary data derived from field survey with the help of four surveyors, each surveyor is assigned to a different location. The primary data is based on results obtained 
from a preliminary survey, the time of data collection is on Sunday during the morning rush hour (7:30 to 11:00 pm), mid day (11:30 to 14:00 pm) and afternoon (14:30 to 18:00 pm).

b) Secondary data

Secondary data is required to support analysis, in this study secondary data is the form of land area used for shopping district, parking area in square meters, type of parking, as well as road width in the study area. The data was obtained from the relevant agencies as well as the manager of the shopping district.

\subsection{Data Processing Method}

In this study the method of data analysis was done by using a time interval for 15 minutes for each survey period. Then a graph representing the amount of accumulation and the volume of parking was created. Likewise with the duration data or length of parking time, a graph representing the relationship between the number of vehicles and parking time was also created.

\section{Results and Conclusions}

From the primary and secondary data that have been obtained it can be seen that Jl. Kapasan Surabaya is a four-lane primary collector road with median (4/2 D). Each lane has 3.5 meters width and the direction of separation is 70:30. There is no road shoulder, but there are only curbs and has a width of 1 meter each. Based on observations and analysis that has been done, then the parking characteristics of the J1.Kapasan shopping district can be described as follows:

\section{Parking Accumulation}

The data obtained for parking accumulation shows that the highest occupancy rate is at 1:00 p.m. to $2: 00 \mathrm{pm}$. This is because at this time the condition of the shopping area is at the peak of the crowd. While the lowest occupancy rate is at 7:00 a.m. to 08:00 a.m. due at that time most of the merchants at the shopping center has not started to open their stores.

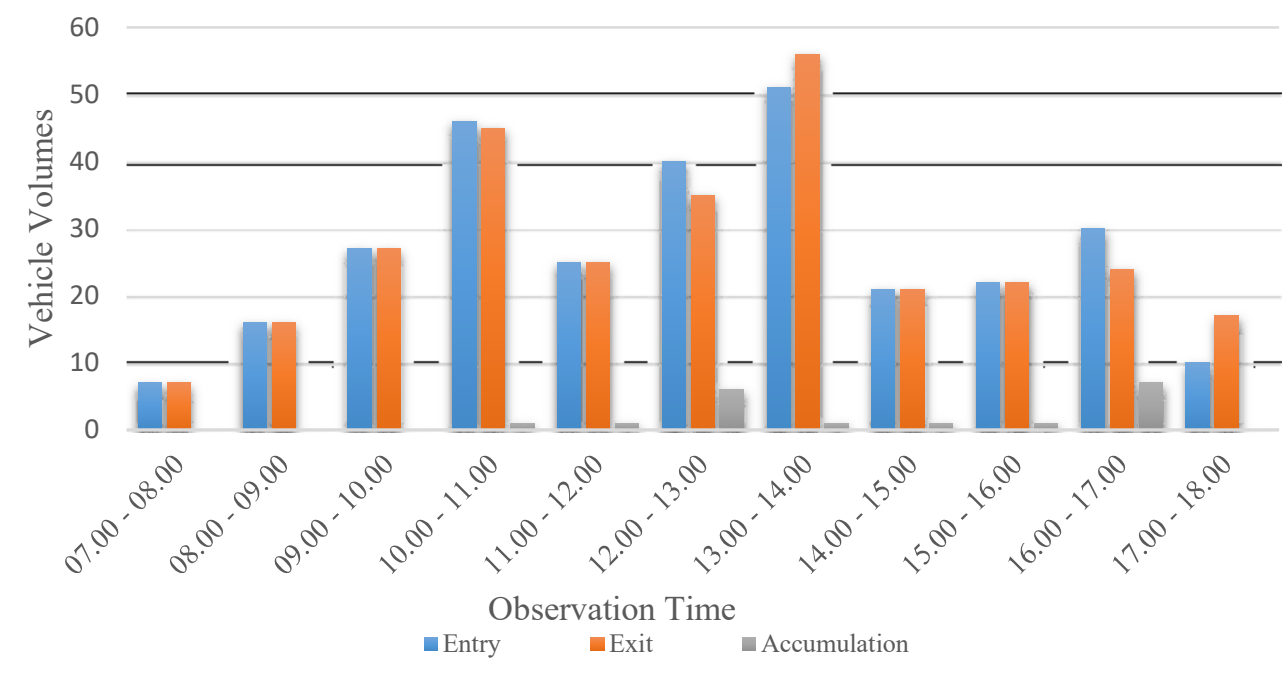

Fig. 1. Parking Accumulation

\section{Parking Volume}

Similar to parking accumulation, from the survey data it was obtained that highest parking was at 1:00 p.m. to 2:00 p.m. in the amount of 52 vehicles. From 07:00 p.m. to 8:00 p.m. was the lowest 
parking volume that was only 7 vehicles parked on the road, and increased sharply at 10:00 p.m. to $11: 00$ p.m. in the amount of 47 vehicles.

\section{Parking Space Units}

Parking on the road along Jl.Kapasan shopping district mostly used by 4 -wheel vehicle i.e. a passenger car class I. Vehicles included in this form of class I are sedans, jeeps, pick-ups or small trucks, and buses. Therefore, in this study the calculation of on-street parking is limited to those types of vehicles. The highest parking space requirements is 598 square meters and the lowest is 80.5 square meters. Required parking space at certain time intervals can be seen in the following pie chart:

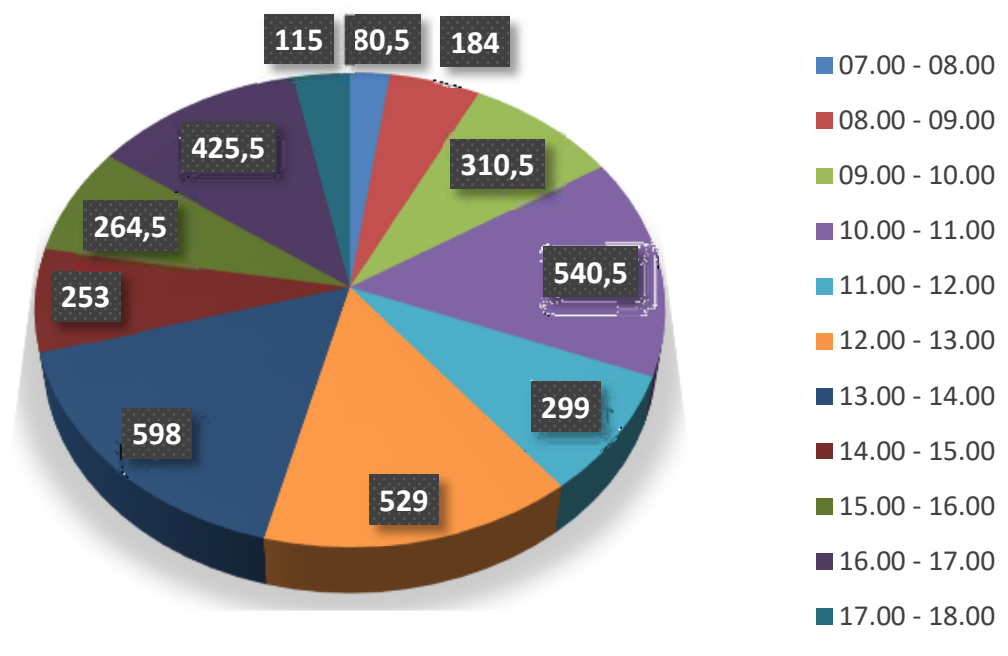

Fig. 2. Parking Volume

\section{Road Capacity}

To determine the capacity of the road in Jl.Kapasan segment, then the calculation was done by using the formulation obtained from Indonesian Highway Capacity Manual 1997 (IHCM 1997). The calculation is made on condition without parking on the road, and when there is parking along the road in a shopping district Jl.Kapasan. The difference lies in lane width factor (FCW) and the side friction factor (FCsf). In the condition without on-street parking the $\mathrm{FCw}$ value is 1 , while if there is parking on the road the value of FCW has become 0.56 . For side friction factor in the condition without parking is 0,97 and when there is on-street parking, the adjustment factor is 0.85 . The adjustment factors are shown in the following table:

Table 4. Comparison of Adjustment Factors

\begin{tabular}{lcc}
\hline \multicolumn{1}{c}{ Adjustment Factors } & $\begin{array}{c}\text { On-Street } \\
\text { Parking }\end{array}$ & $\begin{array}{c}\text { Non On-Street } \\
\text { Parking }\end{array}$ \\
\hline Base capacity, Co & 1650 & 1650 \\
\hline Capacity adjustment factor for carriageway width, $\mathrm{FC}_{\mathrm{w}}$ & 1 & 0.56 \\
\hline Capacity adjustment factor for directional split, $\mathrm{FC}_{\mathrm{SP}}$ & 1 & 1 \\
\hline Capacity adjustment factor for side friction, FC & 0.97 & 0.85 \\
\hline Capacity adjustment factor for city size, $\mathrm{FC}_{\mathrm{CS}}$ & 1 & 1 \\
\hline Capacity: Jl.Kapasan Surabaya & 1600.5 & 785.4 \\
\hline
\end{tabular}


From traffic volume data, the number of vehicles passing Jl.Kapasan around the shopping area are converted into units of passenger cars based on the type of vehicle.

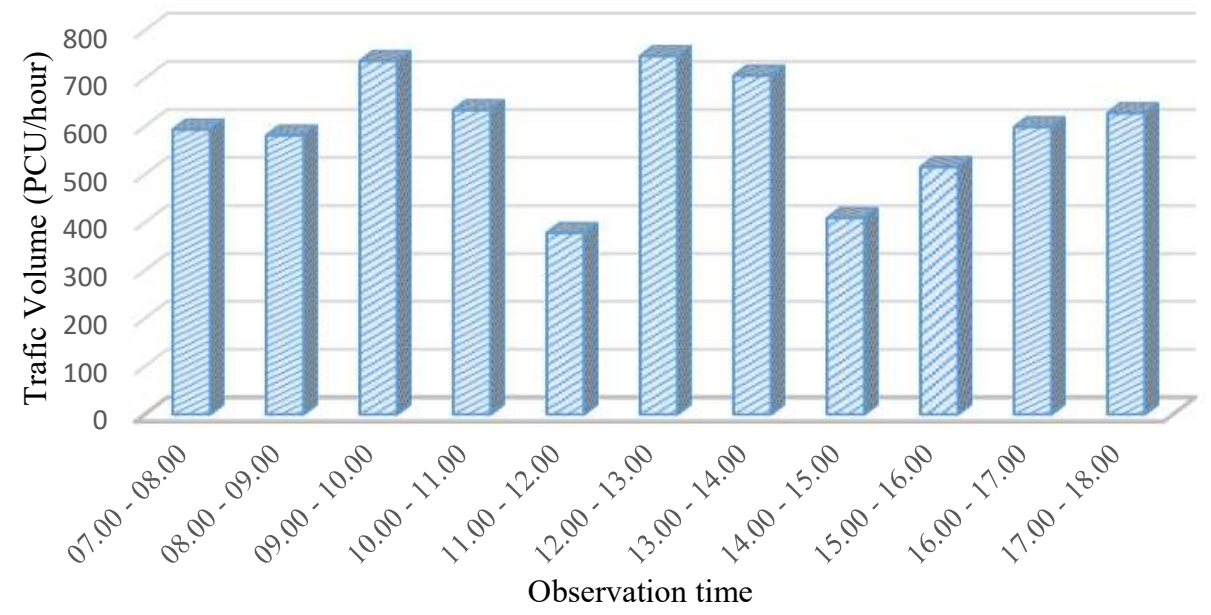

Fig. 3. Traffic Volume (PCU/hour)

Furthermore, from the traffic volume data, the degree of saturation can be calculated. It is obtained by the ratio of volume and capacity of the road. The degree of saturation for each time interval of the study are shown in the following table:

Table 5. Degree of Saturation

\begin{tabular}{ccccc}
\hline $\begin{array}{c}\text { Non On-Street } \\
\text { Parking }\end{array}$ & $\begin{array}{c}\text { Level of } \\
\text { Service }\end{array}$ & Time Intervals & $\begin{array}{c}\text { On-Street } \\
\text { Parking }\end{array}$ & $\begin{array}{c}\text { Level of } \\
\text { Service }\end{array}$ \\
\hline 0.40 & $\mathrm{C}$ & $07.00-08.00$ & 0.47 & $\mathrm{C}$ \\
\hline 0.40 & $\mathrm{C}$ & $08.00-09.00$ & 0.46 & $\mathrm{C}$ \\
\hline 0.50 & $\mathrm{C}$ & $09.00-10.00$ & 0.58 & $\mathrm{D}$ \\
\hline 0.43 & $\mathrm{C}$ & $10.00-11.00$ & 0.50 & $\mathrm{C}$ \\
\hline 0.26 & $\mathrm{C}$ & $11.00-12.00$ & 0.30 & $\mathrm{C}$ \\
\hline 0.51 & $\mathrm{C}$ & $12.00-13.00$ & 0.59 & $\mathrm{D}$ \\
\hline 0.48 & $\mathrm{C}$ & $13.00-14.00$ & 0.55 & $\mathrm{D}$ \\
\hline 0.28 & $\mathrm{C}$ & $14.00-15.00$ & 0.32 & $\mathrm{C}$ \\
\hline 0.35 & $\mathrm{C}$ & $15.00-16.00$ & 0.40 & $\mathrm{C}$ \\
\hline 0.41 & $\mathrm{C}$ & $16.00-17.00$ & 0.47 & $\mathrm{C}$ \\
\hline 0.43 & $\mathrm{C}$ & $17.00-18.00$ & 0.49 & $\mathrm{C}$ \\
\hline
\end{tabular}

Some of the conclusions that can be generated related to the acquisition of data and analysis that has been done are as follows:

1. Based on the calculation of parking space unit, the highest parking space requirements is 598 square meters and the lowest is 80.5 square meters. Analysis of the capacity of the road indicated that there is a difference between the capacity of the road if there is on-street parking and non on-street parking, the amount is $192 \mathrm{pcu} /$ hour. The vast majority of traffic through JL.Kapasan is quite disturbed, shown by the level of service that was predominantly C. It means the freedom to maneuver within traffic stream is noticeably restricted.

2. Parking volume and accumulation reached its highest amount of 47 vehicles and the lowest was only 7 vehicles. 
3. The level of service D occurred at 09:00 a.m. to 10.00 a.m while most of the merchant has already opened, and from 12:00 p.m. to 02:00 p.m when the market is very crowded.

\section{References}

[1] Barter, Paul. On-Street Parking Management, An International Toolkit. Sustainable Urban Transport Project.

[2] Shoup, Donald. 2013. On-Street Parking Management v. Off-Street Parking Requirements. The Access Almanac.

[3] Directorate General of Land Transportation. 1996. Technical Guidelines for The Implementation of Parking Facilities.

[4] Highway Capacity Manual. 2000. Transportation Research Board.

[5] Ministry of Public Works. 1997. Indonesian Highway Capacity Manual (IHCM).

[6] National Programme on Technology Enhanced Learning (NPTEL). Traffic Measurement Procedures, Module 2. India: Government of India. 